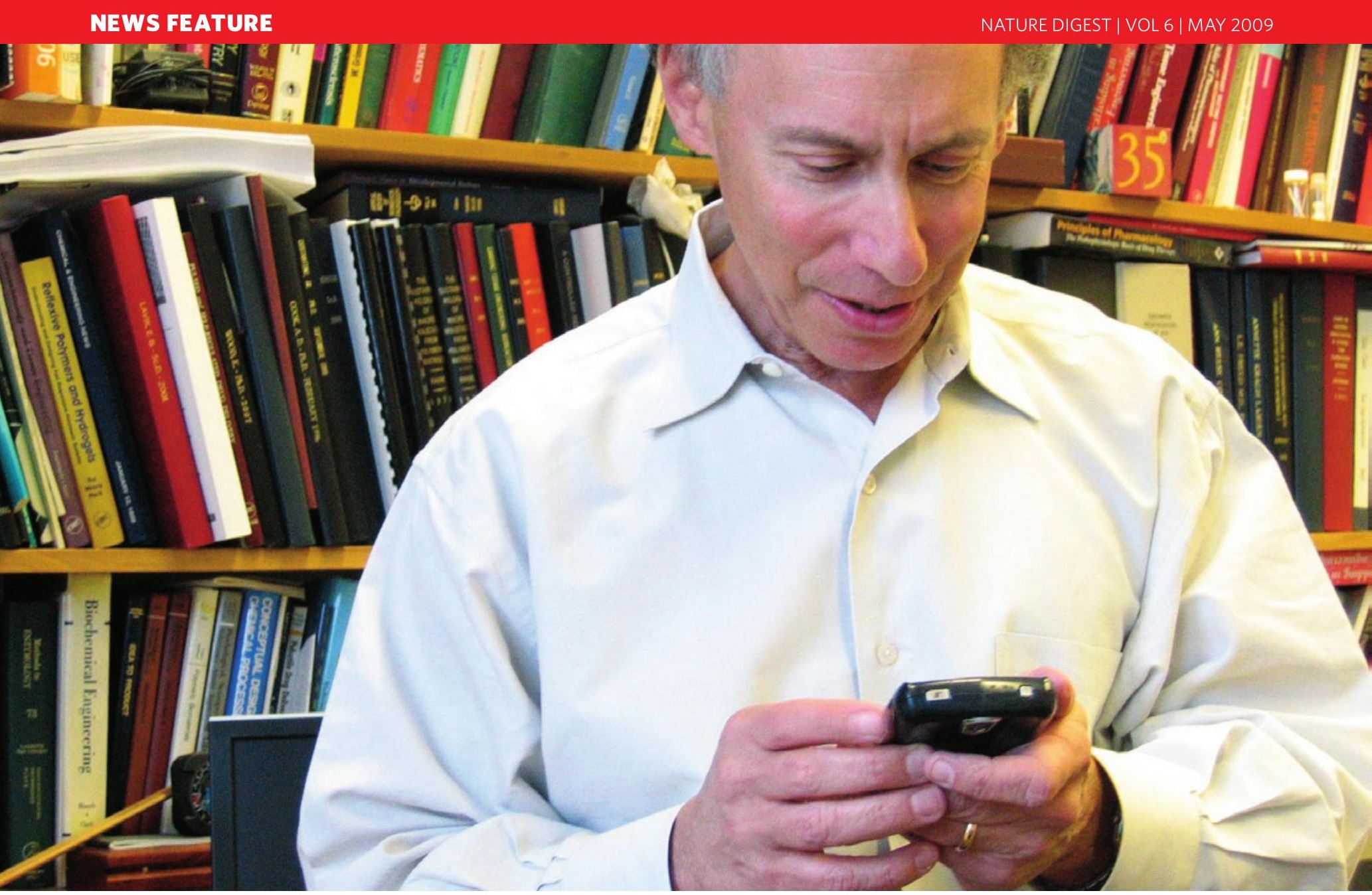

\title{
Being Bob Langer
}

\section{敏腕 MIT 教授のブラックベリ一な 1 日}

Nature Vol.458(22-24)/5 March 2009

マサチューセッツ工科大学 (MIT) の化学工学者Robert Langer 教授は、米国の学術研究機関で最も大きな研究室の 1 つを運営 している。研究室には 100 人近い人々が出入りして、日々、彼の助言を得ている。さらにLanger は愛用のスマートフォン、ブラッ クベリーを通して多くの仕事をこなし、世界中にある種の安らぎを与えている。光んな人望厚く、多忙な彼の 1 日に、Helen Pearsonが密着した。

1 月の底冷えした火曜日の午後 4 時 26 分。Robert Langerは MIT の彼の才 フィスに、ハーバード大学の学部 1 年生、 Lulu Rebecca Tsao を迎え入れていた。 昨年、彼女の継父と Langer がともにフィ ンランドでミレニアム賞財団から賞を受け 取ったことがあり、2 人はその際に一度顔 を合わせたことがあった。この日は、MIT と同じマサチューセッツ州ケンブリッジに
あるハーバード大学に在籍する彼女が、 どういった研究プロジェクトに参加すべき か、Langerのアドバイスを求めてやって 来たのだった。Langerは「研究室を見 せてあげましょう」と申し出た。「簡単に でも見せていただけるなら、とても光栄で す」とTsao は答えた。

実際、研究室の案内は簡単なもので なければならなかった。私は、Langer
のスケジュールを管理している秘書の Bethany Dayが印刷してくれた、この 日の 3 ページにも及ぶスケジュール表を 持っていた。朝食後（彼が朝食をとって いたなら、だが)、今日おそらく 14 番目 となる面会の約束まで、あと 4 分。彼の 研究室は、4 分で見て回れるようなもので はない。4 時間あっても怪しいくらいだ。 Langerの研究室は化学工学科で最も大 
きく、MIT でもおそらく最も大きい。研究 責任者 (PI) 1 人あたりの研究室としては、 世界の学術研究機関の中で最も大きなも のの 1 つだろう。広さは 1300 平方メ一 トルあり、MIT の E25 棟のこの階のほと んどと、上の階の一部を占めている。し かし、Langer はそうしたことは何もいわ ない。彼は、ポスドクを紹介したり、胚性 幹細胞（ES 細胞）の培養装置のところで ちょっと立ち止まったりしながら、部屋か ら部屋へと私たちを案内した。ドアのとこ ろでは、秘書が印刷してくれた暗証番号 のリストを眼鏡の上の緑越しに見ては、注 意深くその数字を打ち込んだ。

Langerは 80 人を超えるメンバーを抱 える研究室を運営し、1000 本を超える 論文を書き、300 件を超える特許を持ち、 さらにそれとほぼ同数の特許を出願中 だ。それらの特許に基づき、200 社を超 える企業に使用許可あるいは二次使用許 可が与えられている。そのうち 25 近くの 企業の設立に、Langer 自身が重要な役 割を果たした。彼の 73 ページある履歴 書 (小さなフォントで行間が詰まっている) は、1970 年に得たコーネル大学（ニュー ヨーク州イサカ）の化学工学の学位に始 まり、生分解性の形状記憶ポリマーに関 する特許出願中の研究でひとまず終わっ ている。私は、そのような途方もない生 産性がどうして可能なのか、そして彼は なぜそれほどまでに仕事をするのか、そ の感覚をつかむため、彼と 1 日を過ごす 取材に訪れた。

後者については、Langer はこう答えて くれた。「人々の手助けをしてその人たち を幸せにし、この世界に貢献したいだけ です。人はいい状態にあって自信を持て ば、自分自身で問題を解決していくことが できます」。この言葉を取材前日の夜に初 めて聞いたとき、正直なところ、よくある 決まり文句にすぎないなと思った。しかし、 この日のタ方、先の研究室案内に同行し ているころには、それはかなり率直な真 実だと思うようになっていた。

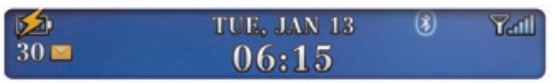

起床して短パンに足を通す。彼の父が心 臟病で 61 の歳に死んだとき、当時 28 歳 だった Langer は肉を食べるのをやめ、 運動を始めた。今では 2 時間以上の運動 が日課だ。現在 60 歳の彼は自宅にジム を持ち、そこで仕事や読書をする。ときど きは、ジムのマシンの操作卓でメモを走り 書きすることもある。この朝、彼はボスト ングローブ紙を読み、ビルアンドメリンダ. ゲイツ財団などが進めている世界的な医 学保健研究計画「グランドチャレンジ・イ ン・グローバルヘルス」のために彼が審 査を担当している研究助成金の 200 件近 い応募に目を通し始め、お気に入りのカン トリーミュージックを聞いた。朝食は抜い て、ダイエットコークを何口か飲んだ。

この最初の数時間については伝聞だと いうことを、認めなければならない。私 は、起床から就寝までともに過ごす取材を 申し入れたが、Langerは妻と相談のうえ、 （もっともなことだが）これを丁重に辞退 したからだ。

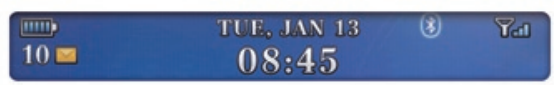

彼のオフィス近くのホテルに泊まっている 私を、自らの運転で拾ってくれる。車はべ一 ジュ色のメルセデスベンツE350。ホテル とオフィスはわずか数ブロックの距離だっ たが、オフィス到着までの間に、彼が起こ したバイオテクノロジー企業 2、3 社の前 を通過した。Langerは、1980 年代に 自身初めてとなるコンサルティング料を受 け取ったとき、くたびれたフォードのピン トからメルセデスベンツ A クラスに乗り換 えたという。そしてその後は 5 年ごとに新 車に買い換えている。

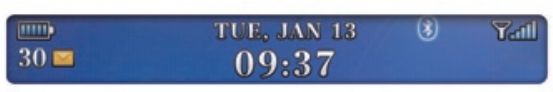

私は今日、唯一の取材者ではなかった。 別のビデオ撮影チームがLangerのオ

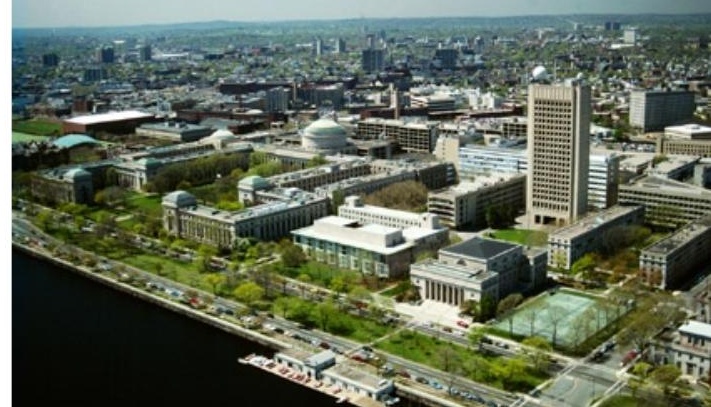

Robert Langer 教授が働くマサチューセッツ工科 大学（MIT）のキャンパス。彼はこの中で 1300 平方メートルもの広さの研究室を運営しており、抱 えるメンバーは 80 人を超える。また彼は昨年、ミ レニアム技術賞、マックスプランク研究賞、アストゥ リアス皇太子賞などを受賞し、賞金の総額はおよそ 200 万ドル（約 2 億円）にのぼった。

フィスで準備している。Langer はジャケッ トを着て（黒のジーンズと茶色の靴は、 画面には写らない)、彼の業績に関する 質問に答え始めた。これは、工学のノー ベル賞とよばれることもある賞金 50 万ド ル（約 5000 万円；1 ドル $=100$ 円で 換算、以下同）のチャールズ・スターク · ドレイパー賞のウェブサイトにアップされ る教育ビデオの撮影だった。彼は、同賞 を 2002 年に受賞している。撮影のまと め役の女性によると、「撮影の約束を取り つけることができなかった受賞者もいます が、彼は喜んで取材に応じてくれました」 とのこと。

Langer は最近、「Outliers（邦題仮訳： 異端者たち)」という本を読んだという。 ジャーナリストの Malcolm Gladwell が、特別にすぐれた人々が現在の地位に 達したのは、特別にすぐれた能力や努力 というよりも、部分的にいえば、特別に惠 まれた環境のためであることを論証したも のだ。これには Langerも納得した。加 えて彼は、「不屈の意志とリスクをとるこ と。成功にはどちらも必要で、さらに、ま あまあ頭がよいこと、何かすばらしいこと をしたいという気持ちがあることも必要 かもしれない。その人の持つ資質という 側面は確かにある」と話す。しかし、ど ういうチャンスにめぐり会うかという面も ある。石油会社では働きたくないと思って いた若き化学工学者だった Langerは、 教職か医学部での仕事を探した。やがて 
ハーバード大学のJudah Folkman が血 管成長を抑制する分子を単離するという仕 事を与えてくれるまで、彼は成功とは無緑 だった。しかし、そこはLangerにぴっ たりの場だった。興味深い医学的問題が たくさんあり、それが彼の工学的ノウハ ウと構想力で解決できるかもしれないこと に、Langerは興奮した。まるで「お菓 子屋さんの中にいる子ども」のようだった という。彼はFolkman が求めていた血 管新生抑制剂を単離し (R. Langer et al. Science 193，70-72；1976)、続いてそ うした大型分子が放出される速度を制御 する多孔質ポリマーを作った（R. Langer and J. Folkman Nature 263, 797 800；1976)。これらのアイデアは、受け 入れられるまでいくらか時間がかかった。 生物学者もポリマー化学者も当時、彼ら のアイデアをばかげているとみなした。し かし現在では彼は、放出制御ドラッグデリ バリー(薬物送達) とティッシュエンジニ アリング（組織工学）の分野を切り開い た研究者として評価されている。

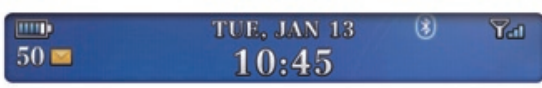

MIT のナイト科学ジャーナリズ・ムフェ ローシッププログラムの責任者である Phil Hilts が、ジャーナリストの教育プロ グラムに招くナノテクノロジー専門家の人 選についてアドバイスを求める。彼で今 日、Langerにアドバイスを求めた人は 15 人目とみられる。誰もが彼の人脈と 経験に基づいたアドバイスを求め、彼は それに応じる。バラク・オバマ大統領も 著書『合衆国再生一大いなる希望を抱い て (原題 : The Audacity of Hope)』 の中で、幹細胞研究について 2006 年に Langerにアドバイスを求めたことを書 いている。Langerはそのとき、「幹細 胞株を増やすことは有用だが、私たち科 学者にとって本当の問題は、連邦政府の 助成金が大きく削減されていること」だ と答えている。

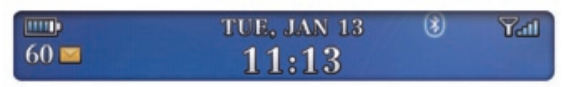

トイレへの行き帰りで、 7 件か 8 件の電子 メールを処理する。その中には、米国科 学アカデミー紀要への掲載が検討されて いる論文についての編集上のアドバイスも あった。そしてここにもう 1つ、オバマ大 統領との接点が隠されていた。Langer もまた、ブラックベリー（携帯電話と携帯 情報端末を融合させたスマートフオンの一 種で、欧米で広く使われている）が手離 せないのだ。彼は、誰かと直接話してい ないときはいつも、特徴的な前屈みの姿 勢でブラックベリーを柕き込んでいる。一 方、彼のコンピュータには今日は、今の ところ電源すら入れられていない。その 処理能力を使っても、一本指でタイプする Langerが返信を送る速度にはほとんど 差はないだろう。そもそも大きな差はあり えない。人々が Langerに電子メールを 送り、彼のブラックベリーからそのクロイ チゴの名のとおり実の多い返答を受け取 るまで、数分以上かかることはめったにな いからだ。

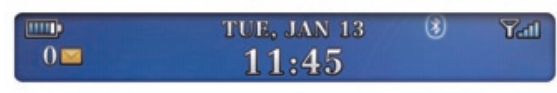

私たちは、彼がこれから講義を行う教室 へ向かった。雪の積もった MIT のキャン パスを歩いて横切る途中で、新たに建設 中の David H. Koch がん総合研究所の 茶色の足場を彼は指差した。彼の研究室 は2010 年にそこへ移る。「研究室の広 さは約 1900 平方メートルに増えますが、 スタッフを増員するのではなく、既存の研 究室メンバーに、より多くのスペースを与 えるつもりです」。

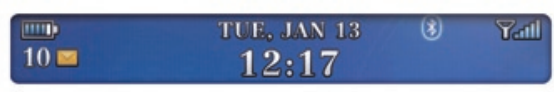

Langer はベジタリアン用のラザニアと チョコレートクッキーを急いでロに入れ、 それから講義を始めた。(ちなみに、もう 1 人のフルタイムの秘書 IIda Thompson
は、6つか 7 つのひな型から場面に応じ てLangerが話すべき内容を事前にまと めておくことが主な仕事だ。）この講義は 学部学生向けのもので、例えば、企業の 起こし方といった現実社会の問題について 教えるプログラムの一部だ。プログラムディ レクターのSusann Luperfoyは、「きょ うは工学分野におけるタイガー・ウッズ、 マイケル・ジョーダンに来てもらいました」 といって彼を紹介した。

\begin{tabular}{|c|c|c|c|}
\hline $\begin{array}{l}\text { (ini); } \\
13 \square\end{array}$ & $\begin{array}{c}\text { TUE, IAN } 13 \\
12: 28\end{array}$ & (자) & Tanll \\
\hline
\end{tabular}

バイオテクノロジー企業を興そうとわずか でも思っている人は全員、この講義を聴く ベきだ。ベンチャーキャピタルの浪費を数 百万ドル（約数億円）節約できるだろう。 Langer は、バイオテクノロジー企業を始 めるために必要なものを明確にリストアッ プした。基盤となる技術、将来性のある 論文、ブロッキング特許（抑止特許）を持っ ているか。もしなければ、困難に直面す るだろう。それから彼は、自身のサクセ

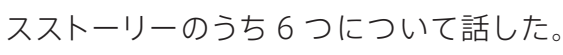
Langerの話がまとめに入ると、同じ机に いた私の隣の学生は「すごい…」とつぶ やいた。

講義後、彼のオフィスへ戻ろうと歩いて いると、小さな火星探査車が現れ、雪の 中を進んで行った。「MITではこういうこ とが起こるんですよ」と彼はいった。

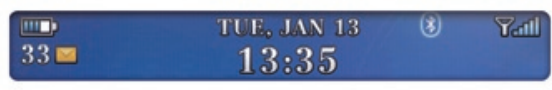

Langerは、かつての研究室のポスド ク、Smadar Cohenを抱きしめていた。 Cohenは現在、イスラエルのテルアビ ブにあるベングリオン大学の教授である。 「現在、自分自身の研究室を率いている 元学生や元ポスドクは、180～200人ほ どいます。彼らのことほど誇らしく思うも のはありません」とLangerは話す。と ころでCohenは今、イスラエルのハイファ にあるファーメディカ社という企業にかか 
わっている。ファーメディカ社は、バイオ テクノロジーの有望な学術研究プロジェク 卜の事業化を行う会社だ。Cohen と最高 経営責任者の Yoram Rubin が飛行機で ケンブリッジへやってきたのは、主として Langer との 30 分の面会のためだった。 彼女たちの質問は、どうやって資金を集 め、どの分野を専門にすべきかであった。

Langerは、「ベンチャーキャピタリス 卜を説得して自分たちが考えている総額 1000 万ドル（約 10 憶円）をすべて出 資させたいなら、会社は事業の製品化 にできるだけ近づいている必要がありま す。いつも思うことですが、投資をしても らいたいなら、ここで投資しなければ何 か大きなものを失ってしまう、というくら いのおそれを相手に抱かせないと」と話 した。事業の専門化については「何が最 先端の分野で、誰が知的財産権を持って いるかを考える必要があります」とアドバ イスした。神経科学は有望な分野だとい う点で、彼らの意見は一致した。しかし、 Langerは「制約は、あえてそれが必要 になるまでは設けないほうがいいですよ」 とも話した。

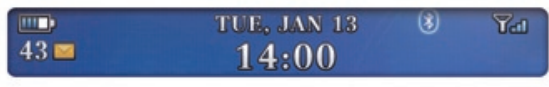

約束の相手が現れない。Langerの研 究室に 2 年半所属してきた学部学生の Natalia Rodriguezは、Langer とこれ まで 1 対 1 の面談をしたことがなかった。 今日、彼女は 15 分の面談を予定してい た。彼女はいったいどこ?

\begin{tabular}{|c|c|c|c|}
\hline 밈 & $\begin{array}{c}\text { TUE, JAN } 13 \\
14: 16\end{array}$ & (자) & $\nabla+010$ \\
\hline
\end{tabular}

つまりのところ、Langer は MIT のE25 棟に彼自身の学際的研究所を作ったとい える。ここにいるのは化学工学者、細胞 生物学者、化学者、物理学者、材料科学 者、遺伝学者、医師、機械工学者、数学 者たちだ。「多くのスタッフなしには、今 私たちがしているような数多くの研究がで
きるとは思いません」と彼はいう。この 研究グループを運営するために、彼には 右腕となるスタッフが 3 人いる。彼らはそ のために選ばれた MITの上級研究員だ。 その 1 人、Dan Anderson が、研究 室をさらに拡大する相談をするため、才 フィスにやってきた。Andersonは「さ らに多くの人を雇う必要があります。ま た、どうやって人材を獲得するかも考えな いと」と話し始めた。研究室をさらに拡 大しなければならないのには理由があっ た。脺島細胞を包む生体親和性ポリマー の開発に多額の助成金を出してくれた若 年性糖尿病研究財団が、免疫学者を研究 室に加えることを勧めたためだ。彼らは、 別の研究室と共同でポスドクを雇う案も 検討したが、やがてLanger は、「研究 室専属のスタッフを持つほうが簡単だと 思う」といった。そして全米アカデミー会 員名簿を本棚から取り出すと、免疫学の ページを開いた。「ここに掲載されてい る人たちのかなりを知っている。Frank Austen,Fred Alt, Irv Weissman。 Weissmanは組織工学に本当に興味を 持っているようすだよ」。

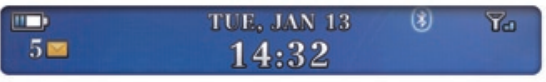

Charles Jennings は、知的財産権問題 について Langer と相談したかった。彼 はMITマクガバン脳研究所の神経テクノ ロジープログラムの責任者で、同研究所 所属の研究者による発見の知的財産権に 関して、同意書を作成する必要性に迫ら れていた。ある意味、これは、将来の収 入について結婚前に取り決めるようなも のだ。MITの方針では、知的財産権によ る収入は一般的に、発明者、所属学科、 MITの 3 者で分配する。Jenningsは、 マクガバン脳研究所ではこれをどのように 取り扱うかの草案を作った。この研究所で は、いくつかの学科にまたがる共同研究 がよくある。Langerは、MITの脳・認 知科学科はこの取り決めでは納得しない

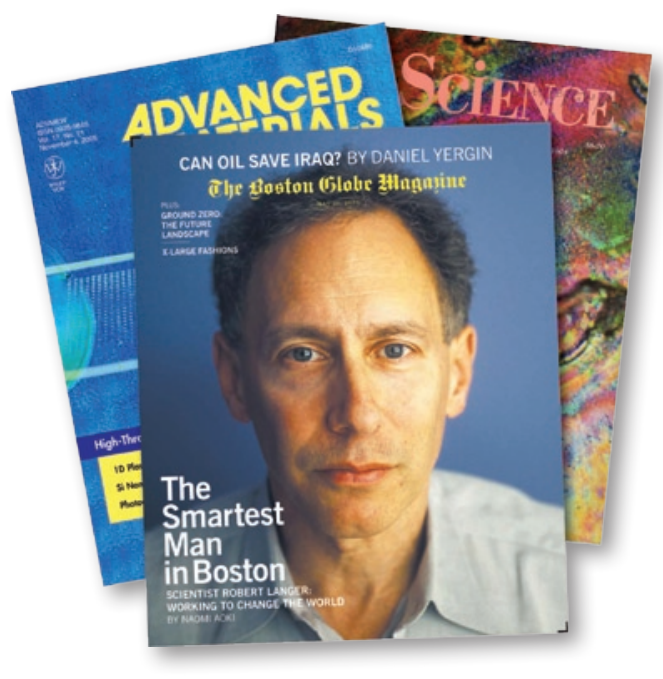

Robert Langer の論文はAdvanced Materials 誌、 Science 誌の表紙を飾り、彼自身もボストングロー ブ・マガジン誌の表紙になった。

かもしれない、と心配した。「脳・認知科 学科長が 3 年後になって『いったいどう やってうまくやったんだ? こちらは何も 得られないのに、そっちは $100 \%$ を得る なんて』と文句をいうようなことになった ら‥」 Langerがいうと、皆も「それ はまずいな」と口を揃えた。

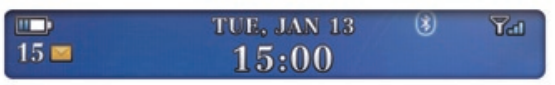

香水の香りが部屋の空気を満たした。 Rob Robillard ときれいに化粧をし た 3 人の若い女性 (Jamie、Amber、 Michelle) が列を作ってオフィスに入って きた。Langerが起こした企業は、生物 医学関連の装置や創薬、デリバリーシス テムなどの製造会社が多いが、アンドラ社 （現在はリビングプルーフ社という）の設 立も手伝った。ケンブリッジにある同社は 化学工学を応用したへアケア製品や美容 製品の開発を手がけており、Robillard はその最高経営責任者だ。

同社の最初の製品「ノーフリーズ」(フ リーズはちぢれ毛の意味) は、毛幹のす き間をふさぎ、水分が入り込まないよう にする。その結果、名前どおりの効果が 
あるという。3人の若い女性は、製品が 2 月に公式に発足されたのち、米国中を まわり、美容コンサルタントの訓練を行う ことになっている (QVC テレビショッピン グチャンネルでも売り出される)。「ノーフ リーズは、すでにMIT のキャンパス中に 広がりをみせています」とRobillardは 話す。Langerは、この企業の設立にか かわったおかげで、彼のちぢれた髪を一 流のへアデザイナーに無料で切ってもらっ ている。

\begin{tabular}{|c|c|c|}
\hline 四 & $\begin{array}{c}\text { TUE, IAN } 13 \\
15.30\end{array}$ & (3) \\
\hline
\end{tabular}

Langerは、面会の時間枠を 15 分ある いは 30 分とし、さまざまなアドバイスを している。コース選びについてのアドバイ スを求める学部学生に対しては「あなた が学べる最も重要なことは基礎です」とい い、企業への就職あっせんを望むなら「そ れを取りもってあげることはできますよ」 と話す。彼は、Tsaoに研究室の案内をし た。彼のシャツのボタンが、いつのまにか 1 個はずれていた。Langerは以前、もっ とうまくノーということができたら」とこぼ したことがある。しかし、「人々の感情を 傷つけたくはないから」とも彼はいう。

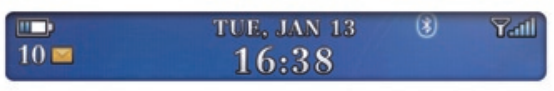

私たちは、Rodoriguez との面談の時間 に少し遅れた。彼女の先の面談時間は変 更になっていた。彼女はエレベーターの 中に 45 分間閉じ込められ、それで本来 の時間に来られなかったのだ。彼女は泣 き出しそうだったが、それはエレベーター のせいではなく、メルク社の採用に応じる か、大学院に行くか決めかねていたから だった。Langerは「間違った選択などと いうものはありませんよ」と彼女に話した。 そして「心の中では何をしたいと思ってい るの?」と聞いた。彼女はようやく、「就 職しようと思います」と答えたが、その確 信は持てないようだった。

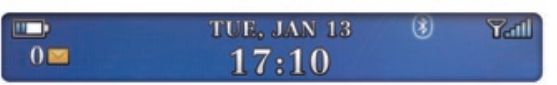

Langerは歩いて上の階の会議室へ。た くさんの人が集まっている。ほかの研究 室なら研究室の全員が集合したくらいの 規模だが、ここに集まっているのは、彼 の研究室に所属している学部学生だけ。 Langerは、学生たちが彼と気軽に話せ る機会を作ろうと、ピザと炭酸飲料を用意 したパーティーを企画したのだ。学生た ちがまず自己紹介をしていく (Langerは 学生たち全員の名前を知っているわけで はないので)。彼らが今かかわっているさ まざまな研究プロジェクトは、この研究室 の活動の幅広さをうかがわせた。幹細胞 の再生、薬剤を放出するコンタクトレンズ、 小さなRNAを届ける脂質の包み、インシュ リン送達のための医用生体材料、DNA ワ クチンなどなど。

学生たちはLangerに尋ねた。気に入っ ている発見は何ですか?「1976年の Natureに載った論文」。旅行にいちばん 行きたいところはどこですか？「パリとマ ウイ島。食事がおいしいところ」。今でも 人前で話すのが苦手ですか? 「ノー」。ど こでアイデアを得ますか? 「テレビ番組、 音楽、読書。決まった方法はないよ」。ど うやっていろんなことのバランスをとって いるのですか? 「よく運動すること」。も し、すべてをやり直すとしたら何を変えま すか? 「何も変えない」。米国は将来も 科学研究の大国であり続けますか? 「イ エス」。あなたにとって最悪の失敗はなん でしたか? 「失敗も何かを教えてくれる ものだ」。彼は、 3 切れのピザを食べる間 に質問のすべてに答えた。

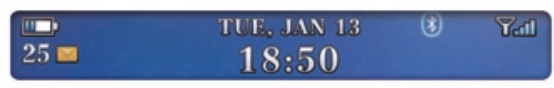

私たちがオフィスを出るとき、Langerの コンピュータはまだ使われないままだっ た。彼はホテルまで私を送り届けてくれ た。私は疲れきっていた。自宅への帰り 道、彼は車を止めてアイスクリームを買っ
た。熱いファッジソースのかかったコー ヒーチップ・フローズンヨーグルト。自 宅に戻ると、ジムでバイクを 1 時間漕い だ。Langerも時にはピープル誌を読ん だり、ボストン・レッドソックスの試合を 見たりする。この夜は履歴書に目を通し、 Angewandte Chemie 誌に投稿する論文の 手直しを行い、月末にスイスのダボスで開 かれる世界経済フォーラムでの講演の準 備をした。それから、娘（3 人いるティー ンエイジャーの子どものうちの 1 人) が金 曜日の化学のクラスで行う発表の練習を するのを聞いてやった。発表はスマートポ リマーに関するものだ。「娘は自分自身で 全部やったのです。彼女は文献を 4 つ引 用して、私にもインタビューしました。私 は彼女の宿題は手伝わないけど、化学に ついてはいくらか説明しました」と彼は話 す。それからもう 1 時間、筋力強化のた めのトレーニングとトレッドミル (ランニン グマシン）をやった。今日はディナー後の 講演の必要もなく、あとは心地よいベッド が待っているだけだ。今夜は比較的くつろ いだ夜だった。

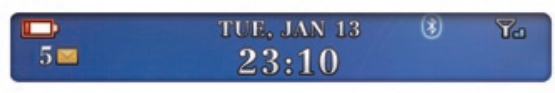

明日はフロリダ州タンパにある米軍再生医 学研究所への出張だ。その荷造りの最中、 Langer はパニックになった。それで、彼 のパスポートと電話は結局どこにあった かって? それは彼のコートの中だった。

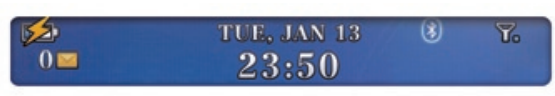

Langer のブラックベリーはバスルームで 充電中だ。本人はベッドの中にいる。彼が 何の夢を見ているのかはわからない。で も、あえてどんな夢だと思うかと聞かれた ら、こう思う。きっとそれは幸せで、彼の 助言で救われた人たちの夢だと—。

Helen Pearson は Nature の生物学特集担当エディ ター。 